\title{
Adsorptive Removal of Cr (VI) from Aqueous Solution onto Charred Sugar Cane Bagasse
}

\author{
Pusp Raj Bhatt ', Ram Lochan Aryal', Bhoj Raj Poudel ${ }^{1}$, Sitaram Bhattarai ${ }^{\text {I and Surendra K Gautam }}{ }^{\text {* }}$ \\ ${ }^{I}$ Department of Chemistry, Tri-Chandra Multiple Campus, Ghantaghar, Kathmandu, Nepal \\ ${ }^{2}$ Department of Chemistry, Amrit Campus, Tribhuvan University, Kathmandu, Nepal
}

Email:sgautam2055@yahoo.com

\begin{abstract}
Charred sugar cane bagasse was prepared by chemical modification of sugar cane bagasse with conc. $\mathrm{H}_{2} \mathrm{SO}_{4}$. The adsorption of Cr(VI) ions on charred sugar cane bagasse (CSCB) has been studied through batch adsorption techniques to evaluate the influence various parameters such as $\mathrm{pH}$, contact time, initial concentration and adsorbent doses. The adsorbent surface was characterized by using Scanning Electron Microscopy (SEM) and functional group was detected by Fourier Transform Infrared (FTIR) spectroscopy. The optimum $\mathrm{pH}$ was found to be 1 and the reaction followed pseudo-second order kinetics. The adsorption percentage of chromium by charred sugar cane bagasse decreased at the higher initial metal concentration and lower adsorbent doses. The equilibrium adsorption isotherm was best fitted with Freundlich adsorption isotherm. This result indicates that SCB can be used as economical and efficient material for the adsorption of Cr(VI) from the aqueous solution.
\end{abstract}

Keywords: Modified Sugar Cane Bagasse (MSCB), Langmuir Isotherm, Freundlich Isotherm, SEM, FTIR

\section{Introduction}

The pollution of heavy metal ion in the environment is a critical problem because of their toxicity and other effects. Chromium is a toxic metal of widespread use in many industries and mixing into the environment as a result of metal plating facilities, mining operation, leather tanning, metallurgy, fly ash from incinerators, manufacture of electrical equipments paints, alloys, batteries pesticides, fertilizers. Chromium has two stable oxidation states $\mathrm{Cr}(\mathrm{III})$ and $\mathrm{Cr}(\mathrm{VI})$. The trivalent form is less harmful but hexavalent chromium is toxic, and mutagenic in nature ${ }^{1}$. Chromium is hard steel-gray metal that is highly resistant to oxidation, even at high temperature. Industries wastages are quite responsible for the spreading the heavy metals in aquatic environment and parallel into the terrestrial environments too ${ }^{2}$. The problem is created due to the contamination of the waste water of urban areas with toxic heavy metals ions. Contamination of these metals and metalloids in lake, stream, and other resources of the drinking water leads to horrendous health problems in animals, plants including human beings ${ }^{3}$.

If the concentration of the $\mathrm{Cr}$ (VI) is slightly greater than its tolerance limit (land surface water 0.1 ppm and potable water is $0.05 \mathrm{ppm}$ ), it becomes toxic and its ingestion can cause pain, vomiting. Classically, chromic metal can be removed by precipitation lime coagulation, solvent extraction,

${ }^{*}$ Corresponding author 
electrolysis, ion-exchange, reverse osmosis, evaporation, chelating, centrifugation, electro-dialysis methods ${ }^{1}$. These techniques are economically expensive and involve incomplete metal removal process. To overcome those problems and to obey more efficient method, it was needed to be practiced efficient and environment friendly methods. Biosorpotion is an efficacious and versatile method for removing chromium and copper and other heavy metals from industrial and other drain wastage. The modified carbon is most frequently used adsorbent for the removal of $\mathrm{Cr}(\mathrm{VI})$ present in water and wastewater that can be employed for the treatment of trace concentration of pollutant ${ }^{4}$. Modified carbon has been prepared from various agricultural waste materials like coconut husk, peat moss, wool, husk of Bengalgram, exhausted coffee, waste tea, banana bark, sawdust, sugarcane dust, rice husk, alpine etc. are the low cost of such carbon precursors ${ }^{1}$. The modified material thus prepared from agricultural wastes however can be modified by various methods like chemical activation, steam activation, thermal activation etc. The effective surface area of the modified charcoal gets modified due to the fractionalization of the raw materials by the chemical modification process ${ }^{5,6}$. The main aim of this study is to explore the adsorption capacity and the kinetics of $\mathrm{Cr}(\mathrm{VI})$ ions onto the sugarcane bagasse.

\section{Experimental Methods}

\section{Preparation of adsorbent}

The raw sugarcane bagasse was collected from juice shop of Kathmandu, was washed with distilled water and dried on sunlight about one week. Then it was grinded by mechanical grinder and was sieved into $250 \mu \mathrm{m}$ mess size. Thus obtained raw sugar cane bagasse is poor efficient for the removal of $\mathrm{Cr}(\mathrm{VI})$ metals. To increase its adsorption efficiency thus obtained raw sugarcane bagasse was subjected with chemical modification by conc. $\mathrm{H}_{2} \mathrm{SO}_{4}{ }^{7-10}$.

\section{Buffer solution}

Buffer solutions of $\mathrm{pH} 4.0, \mathrm{pH} 7.0$ and $\mathrm{pH} 9.2$ were prepared by dissolving buffer tablets in $100 \mathrm{ml}$ conical flasks for each single tablet in distilled water by shaking process.

\section{Preparation of solutions}

$1000 \mathrm{mg} / \mathrm{L}$ of standard stock solution of $\mathrm{Cr}(\mathrm{VI})$ was prepared by dissolving potassium dichromate crystal in distilled water and further diluted with $0.1 \mathrm{~N}$ nitric acid solution to prepare working solutions of desired concentrations of $20 \mathrm{mg} / \mathrm{L}, 50 \mathrm{mg} / \mathrm{L}, 100 \mathrm{mg} / \mathrm{L}, 200 \mathrm{mg} / \mathrm{L}, 500 \mathrm{mg} / \mathrm{L}, 600 \mathrm{mg} / \mathrm{L}, 700 \mathrm{mg} / \mathrm{L}^{9}$.

\section{Effect of $\mathrm{pH}$}

The $\mathrm{pH}$ of $50 \mathrm{mg} / \mathrm{L}$ of $\mathrm{Cr}(\mathrm{VI})$ metal ion was maintained in the range $\mathrm{pH}$ 1-5 using $0.1 \mathrm{~N} \mathrm{HNO}_{3}$ and $0.1 \mathrm{~N} \mathrm{NaOH}$ solutions. $25 \mathrm{mg}$ adsorbent along with $20 \mathrm{ml}$ working solution of $\mathrm{Cr}(\mathrm{VI})$ ion with different $\mathrm{pH}$ was taken and shaken at room temperature for $24 \mathrm{hr}$ to reach equilibrium.

\section{Effect of adsorbent concentration}

The study on effect of adsorbent concentration was carried out using $\mathrm{Cr}(\mathrm{VI})$ ion concentration from 20 $\mathrm{mg} / \mathrm{L}$ to $700 \mathrm{mg} / \mathrm{L}$ at optimum $\mathrm{pH}$. After shaking the sample bottles at room temperature for $24 \mathrm{hr}$ and filtering, the equilibrium concentration of $\mathrm{Cr}(\mathrm{VI})$ ion were measured. From the $\mathrm{Cr}(\mathrm{VI}) 1$ concentration measured before and after adsorption ( $\mathrm{c}_{\mathrm{i}}$ and $\mathrm{c}_{\mathrm{e}}$, respectively) and dry weight of adsorbent $(\mathrm{W})$ as well as 
the volume of aqueous solution $(\mathrm{V})$, the amount of $\mathrm{Cr}(\mathrm{VI})$ adsorbed in $\mathrm{mg} / \mathrm{g}$ at equilibrium are computed by using equation (1),

$$
q=\frac{c_{i}-c_{e}}{w} \times V
$$

\section{Batch equilibrium time studies}

Equilibrium time of the adsorbents for the sorption of $\mathrm{Cr}(\mathrm{VI})$ was investigated at optimum $\mathrm{pH}$ values at room temperature. $25 \mathrm{ml}$ of $20 \mathrm{mg} / \mathrm{L}$ concentration of $\mathrm{Cr}(\mathrm{VI})$ solutions were taken in $125 \mathrm{ml}$ reagent bottle with $25 \mathrm{mg}$ adsorbents and was shaken in a mechanical shaker for $10 \mathrm{~min}, 20 \mathrm{~min}, 30 \mathrm{~min}, 40 \mathrm{~min}$, $50 \mathrm{~min}, 60 \mathrm{~min}, 70 \mathrm{~min}, 80 \mathrm{~min}, 90 \mathrm{~min}, 100 \mathrm{~min}, 120 \mathrm{~min}, 4 \mathrm{hrs}, 5 \mathrm{hrs}, 6 \mathrm{hrs}$ and $24 \mathrm{hrs}$ respectively. The metal ion $[\mathrm{Cr}(\mathrm{VI})]$ concentration was determined by spectrophotometric method.

\section{Batch kinetic studies}

The adsorption kinetic experiments were carried out at optimum $\mathrm{pH}$ for $\mathrm{Cr}(\mathrm{VI})$ adsorption by equilibrating $25 \mathrm{mg}$ of adsorbents in $125 \mathrm{ml}$ stopper bottles containing $25 \mathrm{ml}$ of $20 \mathrm{mg} / \mathrm{L} \mathrm{Cr}(\mathrm{VI})$ solution in each. Separate sets of various samples were kept on mechanical shaker and shaken vigorously. Samples were filtered through filter paper and concentration before and after the adsorption were determined by spectrophotometric method by analyzing the filtrate. The data obtained was tested with pseudo first order, pseudo second order and second order kinetic model. ${ }^{27}$

\section{Results and Discussion}

The sorption of $\mathrm{Cr}(\mathrm{VI})$ in aqueous solution was examined by optimizing various physiochemical parameters such as initial $\mathrm{pH}$, initial adsorbate concentration, contact time, adsorbent dose, desorption study. The absorbance of red-violet $\mathrm{Cr}(\mathrm{VI})$-diphenylcarbazide complex at maximum wavelength $520 \mathrm{~nm}$, i.e., $\lambda_{\max }$ is $520 \mathrm{~nm}$.

Removal of $\mathrm{Cr}(\mathrm{VI})$ was found to be decreased with increase in $\mathrm{pH}$. The maximum removal value was obtained at $\mathrm{pH} 1$ which is an optimum $\mathrm{pH}$ for CSCB as shown in Figure 1. Figure 2 depicts the study of adsorption was carried out in measuring the effect of contact time on the batch adsorption of $50 \mathrm{mg} / \mathrm{L}$ metal solution with $25 \mathrm{mg}$ adsorbent for different time intervals ranging from 10 minutes to 360 minutes. The required time equilibrium for adsorption of $\mathrm{Cr}(\mathrm{VI})$ onto $\mathrm{CSCB}$ was found to be 250 minute.

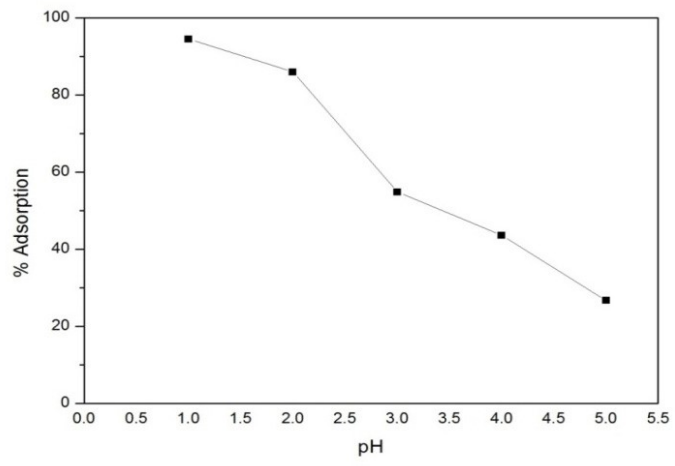


Figure 1: Effect of pH on Cr(VI) adsorption by CSCB

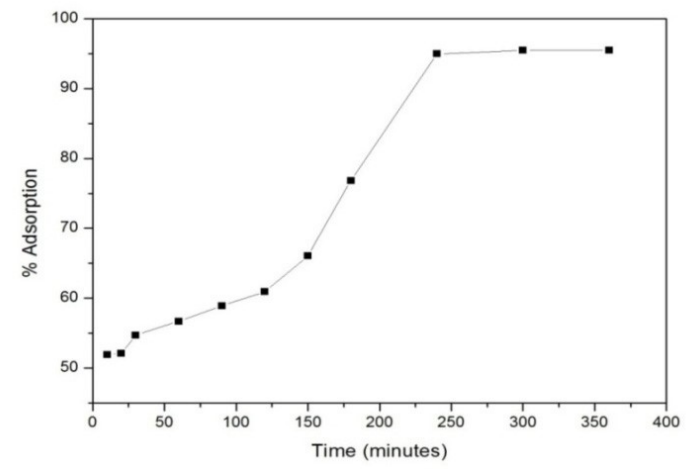

Figure 2: Effect of contact time for the adsorption percentage of Cr(VI) onto CSCB

The effect of adsorbent dose for adsorption of $\mathrm{Cr}(\mathrm{VI})$ onto $\mathrm{CSCB}$ was studied at room tempreture at optimum $\mathrm{pH} 1$ was studied by varying the adsorbent amounts from $25 \mathrm{mg}$ to $200 \mathrm{mg}$ which is graphically shown in Figure 3. The maximum adsorption capacity $\mathrm{Cr}(\mathrm{VI})$ onto CSCB is found to be $100 \mathrm{mg}$ with 93.2 $\%$ adsorption.

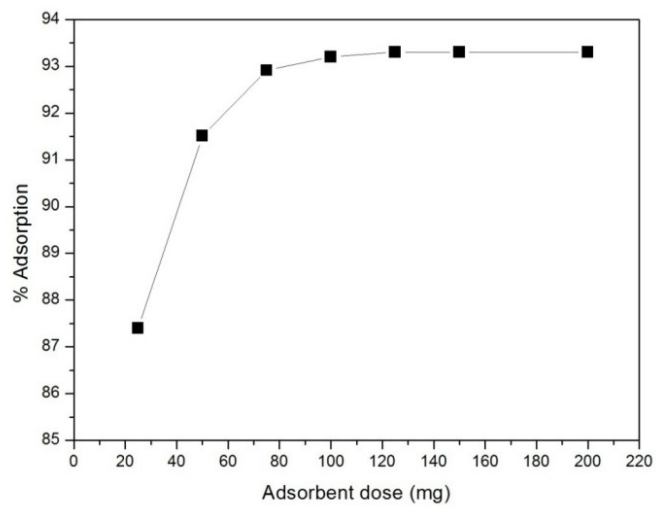

Figure 3: Effect of adsorbent dose for the adsorption percentage of Cr(VI) onto CSCB

Adsorption of $\mathrm{Cr}(\mathrm{VI})$ onto CSCB gives linear relationship with Freundlich and Langmuir isotherms. Freundlich adsorption isotherm is more applicable than Langmuir adsorption isotherm. The values of Langmuir and Freundlich parameters are determined and tabulated in investigated at various concentration from $20 \mathrm{mg} / \mathrm{L}$ to $700 \mathrm{mg} / \mathrm{L}$. Freundlich isotherm plot for the adsorption of $\mathrm{Cr}(\mathrm{VI})$ onto CSCB is shown in Figure 4 as given by equation 2.

$$
\log \mathrm{q}_{\mathrm{c}}=\log \mathrm{K}+1 / \mathrm{n} \log \mathrm{c}_{\mathrm{e}}
$$

Where $\mathrm{q}_{\mathrm{e}}$ is the amount adsorbed per unit pass of adsorbent $(\mathrm{mg} / \mathrm{g}), \mathrm{c}_{\mathrm{e}}$ is the equilibrium concentration of the adsorbent $\mathrm{mg} / \mathrm{L}, \mathrm{K}$ and $\mathrm{n}$ are Freundlich equilibrium co-efficient, which are considered to be relative indicators of adsorption capacity and adsorption intensity. The value of $1 / \mathrm{n}$ varies between 0.1 and 1.0 indicates the favorable adsorption and heavy metal ions ${ }^{11}$. 
Table 1: Langmuir and Freundlich parameters for the adsorption of $\mathrm{Cr}(\mathrm{VI})$ onto CSCB

\begin{tabular}{|c|c|c|c|c|c|c|c|}
\hline Adsorbent & & Langn & uir isoth & & Freu & dlich i & $\mathrm{ms}$ \\
\hline \multirow{2}{*}{ CSCB } & \multirow{2}{*}{319.75} & $\underset{(\mathrm{mg} / \mathrm{gm}}{\mathrm{q}_{\mathrm{m}}}$ & $\begin{array}{c}\text { b } \\
(\mathrm{L} / \mathrm{mg})\end{array}$ & $\mathbf{R}^{2}$ & $\begin{array}{c}\mathrm{K} \\
(\mathrm{mg} / \mathrm{gm})\end{array}$ & $1 / n$ & $\mathbf{R}^{2}$ \\
\hline & & 418.41 & 0.0096 & 0.958 & 3.093 & 0.559 & 0.987 \\
\hline
\end{tabular}

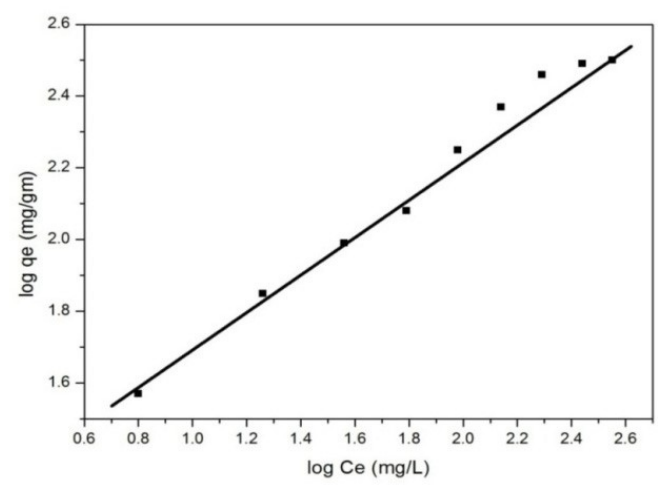

Figure 4: Freundlich isotherm plot for the adsorption of Cr(VI) onto CSCB

The kinetic data for the adsorption of $\mathrm{Cr}(\mathrm{VI})$ onto CSCB was studied by using pseudo-first order, pseudo-second order and second order kinetics model. From these result, the experimental data were better described by pseudo second order kinetics. The plot of pseudo-second order model is shown in the Figures 5. The data for all kinetic models are tabulated in the Table 2. Previous research work is also reported pseudo-second order ${ }^{12}$.

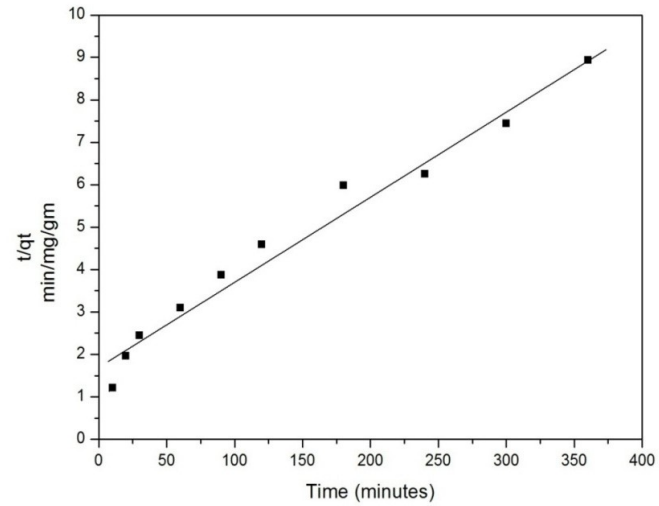

Figure 5: Pseudo-second order kinetic plot for the adsorption of Cr(VI) onto CSCB 
Table 2: Kinetic parameters for the bisorption with correlation coefficient

\begin{tabular}{|l|l|l|}
\hline Order & Rate Constant $(\mathrm{g} / \mathrm{mg} / \mathrm{min})$ & $\mathrm{R}^{2}$ \\
\hline Pseudo first order & $1.06 \times 10^{-2}$ & 0.890 \\
\hline Pseudo second order & $2.315 \times 10^{4}$ & 0.974 \\
\hline Second order & $1.613 \times 10^{-3}$ & 0.64 \\
\hline
\end{tabular}

In present research work, FTIR analysis is performed to investigate the surface functional groups of RSCB and CSCB. The FTIR spectra of both adsorbents (RSCB and CSCB) are shown in Figures 6 and 7, respectively which were used to determine the vibration frequency changes the functional group in the adsorbents of SCB. The adsorption peak around $1635 \mathrm{~cm}^{-1}$ indicates the presence of $\mathrm{C}=\mathrm{O}$ stretching. This is due to the hemicelluloses and lignin aromatic groups. The peak around $1616 \mathrm{~cm}^{-1}$ indicates the $\mathrm{C}=\mathrm{O}$ stretching of aromatic groups, that may be attributed to the hemicelluloses and lignin aromatic groups. This confirms that the changes in vibration of carbonyl group of charred and non- charred sample. The peak around 806 represents the $\mathrm{C}=\mathrm{C}$ alkenes. The peak around $3313 \mathrm{~cm}^{-1}$ represents the free $-\mathrm{OH}$ stretching group ${ }^{13-14}$.

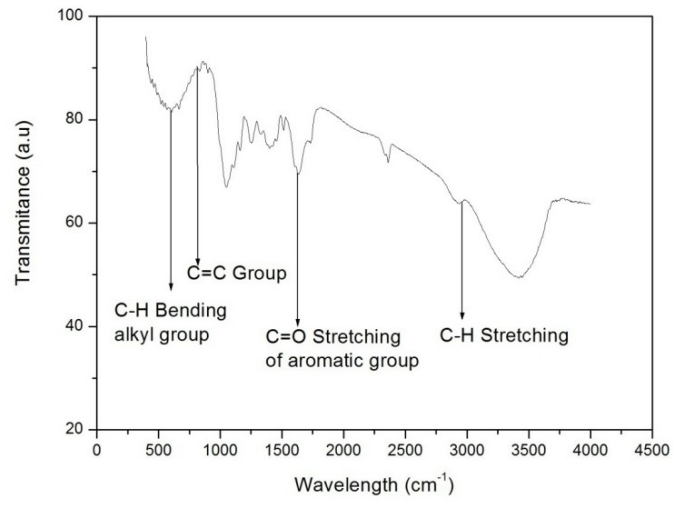

Figure 6: FTIR spectra of RSCB

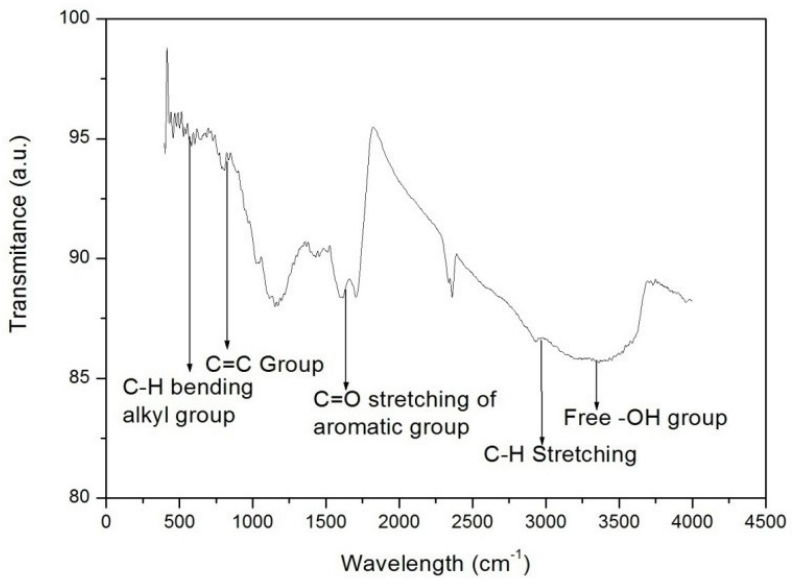

Figure 7: FTIR spectra of CSCB 


\section{J. Nepal Chem. Soc., Vol. 39, 2018}

The Figures 7(a) and 7(b) show SEM images of the raw sugarcane bagasse and charred sugarcane bagasse.

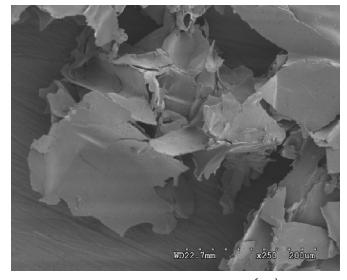

(a)

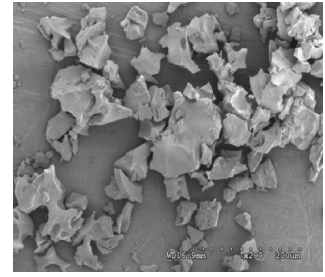

(b)

Figure 7: SEM images of (a) raw sugarcane bagasse and (b) charred sugarcane bagasse

SEM images of charred sugar cane bagasse has smaller particle size with larger surface area and so has greater efficiency to the adsorptive removal of heavy metal ion from aqueous solution as compare to the raw sugar cane bagasse.

\section{Conclusions}

The chemically modified SCB can be used in the separation of $\mathrm{Cr}(\mathrm{VI})$ metal ion from the aqueous solutions which results of the present research work are the optimum $\mathrm{pH} 1$ for the adsorption of $\mathrm{Cr}(\mathrm{VI})$ and the Freundlich adsorption isotherm model with correlation coefficient $\mathrm{R}^{2}$ of 0.987 was more applicable than Langmuir isotherm model $\left(\mathrm{R}^{2}=0.958\right)$. The maximum adsorption capacity of $\mathrm{Cr}(\mathrm{VI})$ onto charred sugarcane bagasse (CSCB) was found to be $100 \mathrm{mg}$. The required time equilibrium for the adsorption of $\mathrm{Cr}(\mathrm{VI})$ onto $\mathrm{CSCB}$ was found to be 250 minutes. The experimental data were better described by pseudo-second order kinetics. FTIR spectrum defines different functional group. SEM image of charred sugar cane bagasse has greater efficient of the adsorption capacity as compared to the raw sugarcane bagasse.

\section{Acknowledgements}

Authors are thankful to Department of Chemistry, Tri-Chandra Campus, Tribhuvan University for providing laboratory facilities to carry out experimental work. Nepal Academy of Science and Technology (NAST) is acknowledged for FTIR spectra and Sogang University, South Korea for SEM images.

\section{References}

1. P. J. Sharma, R. Kumar, N. A. Mankandan and K. Pakshirajan, Asian Journal of Chemistry, 2015, 27(9), 3420-3430.

2. Y. S. Ho, W. T. Chiu and C. C. Wang, Bioresource Technology, 2005, 96, 1285-1291.

3. U. Maheswari and S. Gupta, Adsorption Science and Technology, 2014, 33(1)

4. S. P. Dubey, and K. Gopal, J. Hazard Mater, 2007, 145(3), 456-470. 
5. W. C. Akozlowski and W. Walkowiak, Water Researcch, 2002, 36, 4870-4876.

6. Vogel's Text Book of Quantitative Chemical Analysis $6^{\text {th }}$ Edition Pearson Education Ltd., 2003, 668.

7. S. Bhattarai, Adsorption of $\mathrm{Cr}(\mathrm{VI})$ Onto Raw Rice Husk and Modified Rice Husk Carbon From Aqueous Solution, An Unpublished M. Sc. Dissertation, Central Department of Chemistry, Tribhuvan University, Kathmandu, Nepal (2009).

8. P. Dhungel, Biosorption of Zinc (II) Metal onto Raw and Modified Coconut Husks and Tea Waste, An Unpublished M. Sc. Dissertation, Department of Chemistry, Tri-Chandra M. Campus, Tribhuvan University, Nepal, (2015).

9. B. D. Pant, Adsorptive Removal of Chromium (VI) From Aqueous Solution Onto Charred Vetiver Root, An Unpublished M. Sc. Dissertation, Department of Chemistry, Tri- Chandra Multiple Campus, Tribhuvan University, Kathamandau, Nepal (2014).

10. T. P. Dhungana and P. N. Yadav, Journal Nepal Chemical Society, 2008/2009, 23, 93-101.

11. Y. Busto, E. W. Palacios, I Aloma, L. M. Rios, M. F. Cortez, M. Calero and M. Yera, Chemical Engineering Transaction, 2016, 52, 901-906.

12. S. K. Singh, Indian Journal Science Research, 2017, 13(1), 73-76.

13. M. Bhaumik, C. Noubactep, V. K. Gupta, M. Crindle and R. I. Maity, Chemical Engineering Journal, 2015, 271, 135-146.

14. M. Kobya, Adsorption Science and Technology, 2004, 22(1), 50-64. 